\section{Treasure of Psusennes}

Now that the sarcophagus of Pharaoh Psusennes found on the site of the ancient Tanis (NATURE, February 24, p. 300 ; March 9, p. 382) has been emptied of its mummy and associated jewellery, it has been possible to form a more just estimate of the magnitude of the find. It is regarded as one of the richest discoveries ever made after that of the tomb of Tutankhamen (The Times, March 7). In this collection of remarkably beautiful jewellery, some of the necklaces, as described, are outstanding. One, for example, is composed of two heavy bars of gold supporting a centre-piece in the form of a golden lotus, which is so heavy, it is said, as to emit a gong. like note when the necklace is shaken. Another necklace consists of several huge pieces of lapis lazuli with gold clasps, on which there is an inscription saying that the King had had made for him a necklace which never would be equalled. This necklace scales the remarkable weight of $12 \mathrm{lb}$. Among other objects of jewellery in the find are mentioned further necklaces, two bracelets, golden slippers with a golden case, pins and studs. All the antiquities found, with the exception of the granite sarcophagus, are being transferred to the Cairo Museum, where they will be placed on exhibition forthwith.

\section{Meteorology in British East Africa}

THE director of the British East African Meteorological Service, Mr. A. Walter, describes the work achieved by his Service in 1938 in his annual report for that year. Although described by him as an extremely difficult year, no hint of this would be obtained from a consideration only of the work achieved and the preparations made for extending and improving the activities of future years. Many of the staff fell sick because it had been impracticable for them to take the vacation leave to which they were entitled, and the training of all grades of staff had to be maintained; it was estimated that this would have to be continued for another five years before each section of the Service could become a fully efficient and self-contained unit.

There is much of interest both on the climatological and synoptic sides in this report, and evidence that important contributions to the understanding of meteorological processes are being made. During the course of the year the whole region, which includes Kenya, Tanganyika, Uganda and Zanzibar, has been divided up into zones characterized by peculiarities in the seasonal distribution of rainfall. Seven such zones were found sufficient to cover broadly the observed range of variation, and have been made the basis of a division of the country into forecast areas, which are shown on a map (p. 27). Both daily and weekly forecasts have been appreciated by the resident population and by visitors, an evidence of this interest being the suggestions received for increasing their frequency and extending their range. The weekly forecasts are based mainly on the relative positions of the high- and low-pressure systems on either side of the tropics and the probable changes in the main wind currents connected with them.
They are described as an unqualified success, a fact which is modestly explained as being due to the circumstance that the effects of high or low pressure appearing off the west coast of Africa are generally felt about a week later in the tropical regions of East Africa.

Many planters have stated that their work is planned in accordance with the indications of the weekly forecasts. Local eccentricities of response to general changes are, however, an obstacle to accurate forecasting here as elsewhere, and it is stated (p. 25) that small short-period variations of pressure, temperature and upper winds are showing a significance which would be considered out of all proportion to their magnitude and duration in the meteorology of temperate regions. This report deserves to be regarded as a model for a young progressive meteorological service in the tropics.

\section{Suggested Grid in the United States}

CONFERENCEs have recently beèn taking place in Washington with the officials of some fifty large public utility companies operating in the eastern part of the United States to explore the possibilities of constructing a series of high-voltage lines interconnecting the larger generating plants and powerconsuming centres in this area, including both private and public developments. According to the Electrical Review of February 9, although up to the present no definite plan has actually been made public, the proposals include connecting links that would make it possible to interchange power whenever necessary between such major load centres as Boston, New York, Philadelphia, Washington, Buffalo, Cleveland, Detroit, Chicago, St. Louis, and possibly Birmingham. Connexions would be made with all major generating stations, both steam and hydro-electric, without regard to whether they are controlled by private capital, municipalities, or the Federal Government.

According to preliminary estimates, the construction would cost approximately $£ 100,000,000$. Objections to the plan have been raised owing to the ample generating capacity now in existence or under construction in each of the localities to meet possible future demands. It is also contended that the expenditure of such a large amount would impose an unnecessary financial burden upon consumers of electricity. The advocates of the scheme take the view that the future growth of power demand will be at an accelerating rate and that the rate of construction can be adjusted to actual needs for the new facilities. They are also understood to be relying strongly on the national defence argument, on the assumption that, even though temporarily uneconomic, the Grid can be justified as a safeguard against the power shortages experienced by American industry during the War of 1914-18.

\section{New Radio Transmitter}

Almost unnoticed in the unsettled international atmosphere that existed last August, an extraordinary radio transmitter was inaugurated in the pocket republic of Andorra, which bestrides a small section 
of the Pyrenees on the frontier between France and Spain. A brief account of this station is given in the Electrician of March 8. The President of the French Republic (as successor to the Kings of France) and the Bishop of Urgel in Spain share as co-princes the over-lordship of Andorra, a condition which has lasted since the early part of the ninth century. Radio Andorra is situated on a rocky hill at an altitude of 2,920 ft. above sea-level, but its aerial is placed at an altitude $2,460 \mathrm{ft}$. higher and is suspended across a lake; the supports, $410 \mathrm{ft}$. high, are $820 \mathrm{ft}$. apart. The feeder cable between the station and the aerial is $2,788 \mathrm{ft}$. long and is believed. to be the only case in which a distance of this order separates a transmitter and its antenna, with the exception of the Eiffel Tower, where ultra-short waves had to be considered. At Andorra transmitters for medium and short waves are installed. The energy required for the station is 350 kilowatts and is obtained from the Forces Hydro-électriques de l'Andorra, a water-power undertaking, which sells the bulk of its production outside the borders of this small State.

\section{Illness in Meat Packing Industry}

IN a recent paper (Public Health Rep., 54, 2196 ; 1939) Hugh P. Brinton, assistant statistician, Harry E. Seiffert, assistant public health engineer, and Elizabeth S. Frasier, junior statistician, United States Public Health Service, present an analysis of cases of sickness and non-industrial injuries lasting eight calendar days or longer among workers in the slaughter and meat-packing industry. The annual number of cases per 1,000 was $95 \cdot 0$ for white males, $144 \cdot 2$ for white females, and $137 \cdot 9$ for negro males, while the average number of days of disability per person was $3 \cdot 16,4 \cdot 85$ and $4 \cdot 01$ respectively. Those who showed the highest figures in the form of an excess of respiratory diseases were cold-meat workers among white males, scalers, wrappers and packers among white females, and by-product workers among negro males.

Very excessive rates for rheumatic diseases were found in certain occupations, especially those of warm- and cold-meat workers, sausage and casing workers, and curing workers. As regards environmental conditions, white males exposed to high humidity or wet had the highest rates, with non-respiratory and non-digestive diseases most in excess. Among white and negro males the highest incidence was found among those working in hides and wool, or glue and entrails, among whom digestive diseases were much commoner than the average. White males and white females showed sickness-rates in decreasing order of magnitude as follows: semiskilled workers in manufacturing, labourers, and clinical workers.

\section{New Seismographic Equipment in the United States}

A NEW seismograph station has been established at Lincoln, Nebraska, and new equipment has been installed at Chicago, Salt Lake City, and Bozeman, Montana, all co-operating stations of the United
States Coast and Geodetic Survey, according to J. H. Nelson and H. E. McComb. The new seismograph station is on the campus of the Nebraska Wesleyan University in Lincoln, Nebraska, and is situated on a layer of loess and glacial clay $150-175 \mathrm{ft}$. thick, under which is several hundred feet of Cretaceous sandstone. The position is latitude $40^{\circ} 49 \cdot 1^{\prime} \mathrm{N}$., longitude $96^{\circ} 42 \cdot 2^{\prime}$ W., altitude $358 \pm 5$ metres.

The seismograph operates as an east-west component and is a small experimental McComb-Romberg tilt-compensation seismometer having magnetic damping and a clock-driven completely enclosed recorder. Time control is furnished by a Seth Thomas pendulum clock compared daily with naval radio time signals from Arlington. Tilt compensating instruments have been installed at Chicago on account of the slow irregular tilt movements of the pier on which the seismographs rest. Salt Lake City (latitude $40^{\circ} 45 \cdot 9^{\prime} \mathrm{N}$., longitude $111^{\circ} 50 \cdot 9^{\prime} \mathrm{W}$., altitude $1433 \pm 5$ metres) had a two-component $100-\mathrm{kgm}$. Bosch-Omori seismograph and has recently installed a two-component small model McCombRomberg tilt-compensation seismograph. At Bozeman, oil damping has been replaced by magnetic damping and the recording equipment has been improved.

\section{Smoke Abatement}

The National Smoke Abatement Society has issued its quarterly, Smokeless Air, on a reduced scale but. with a supplement "Smoke Abatement in War Time". This is an effort to rebut the belief that reduction of smoke under present conditions is unimportant. The impression that smoke serves a useful purpose by screening towns against air attack is challenged. A smoke screen may assist a moving object such as a ship, but serves as a landmark fixing the position of a stationary group such as a town. It may provide a screen to hinder the recognition of a specific object, but equally it conceals the attacker from the defence. Concealment is a great help to the submarine, and recent experience shows its assistance to raiding aircraft. The pamphlet directs attention to the way in which colliery tips serve as landmarks, providing a "difficult problem" in smoke abatement. The difficulty, it may be indicated, is less technical than political and due to the fact that the disposal of pit refuse is left to the discretion of the individual colliery. Naturally the cheapest possible method is used, regardless of the effect on the surrounding people, land and of the ultimate cost to the community. The chemical composition of pit refuse is such that self-ignition can scarcely be prevented when it is dumped in enormous heaps. Too often collieries are surrounded by low-lying land reduced to valueless swamp by mining subsidence. Pit refuse would serve a useful purpose, if used to raise the level of such land, and under such conditions firing would not occur.

Smoke results from the liberation of the volatile matter of coal, a large part of which is liquid. Smoke abatement is a movement for collecting this liquid for useful purposes instead of dispersing it as a public 